\title{
Occurrence of the family Pinnotheridae De Haan (Crustacea, Decapoda, Brachyura) on the coast of Ceará State, Brazil
}

\author{
Luis Ernesto A. Bezerra 1; Alexandre 0. de Almeida ${ }^{1,2}$ \& Petrônio A. Coelho ${ }^{1,3}$
}

\author{
1 Programa de Pós-Graduação em Oceanografia, Departamento de Oceanografia, Universidade Federal de Pernambuco. \\ Avenida da Arquitetura, Cidade Universitária, 50670-901 Recife, Pernambuco, Brasil. E-mail: luiseab@gmail.com \\ 2 Universidade Estadual de Santa Cruz, Departamento de Ciências Biológicas. Rodovia Ilhéus-Itabuna, km 16, 45662-000 \\ Ilhéus, Bahia, Brasil. E-mail: aalmeida@uesc.br \\ ${ }^{3}$ Bolsista de produtividade do CNPq. E-mail: petronio.coelho@pesquisador.cnpq.br
}

\begin{abstract}
This study reports the occurrence of Austinixa bragantina Coelho, 2005; A. leptodactyla (Coelho, 1997) and Zaops ostreum (Say, 1817) for the State of Ceará, Northeast Brazil. These records represent the first account of the family Pinnotheridae de Haan, 1883 for the coast of Ceará. A. bragantina was collected on May and June 1995 at Futuro Beach, municipality of Fortaleza $\left(3^{\circ} 42^{\prime} \mathrm{S}, 38^{\circ} 27^{\prime} \mathrm{W}\right)$. This species was previously known only for the type locality, Canela Island, Bragança, Pará, Brazil. A. leptodactyla was collected on November 2004 at Baleia Beach, municipality of Itapipoca $\left(3^{\circ} 08^{\prime} \mathrm{S}, 39^{\circ} 27^{\prime} \mathrm{W}\right)$ and $Z$. ostreum was obtained from the oyster Crassostrea rhizophorae Guilding, 1828, collected on November 2005 at the Jaguaribe River estuary, municipality of Fortim $\left(4^{\circ} 24^{\prime} \mathrm{S}, 37^{\circ} 46^{\prime} \mathrm{W}\right)$. Biogeographic considerations regarding the three species and an updated list of all known Brazilian pinnotherid species along with their_geographic distribution are also provided.
\end{abstract}

KEY WORDS. Austinixa; geographic range; new records; Zaops.

RESUMO. Ocorrência da família Pinnotheridae De Haan (Crustacea, Decapoda, Brachyura) no litoral do Ceará, Brasil. Este trabalho reporta a ocorrência de Austinixa bragantina Coelho, 2005; A. leptodactyla (Coelho, 1997) e Zaops ostreum (Say, 1817) para o litoral do Estado do Ceará, sendo estes os primeiros registros de representantes da família Pinnotheridae De Haan, 1883 para a costa cearense. A. bragantina foi coletada em maio e junho de 1995, na praia do Futuro, município de Fortaleza $\left(3^{\circ} 42^{\prime} \mathrm{S}, 38^{\circ} 27^{\prime} \mathrm{W}\right)$. Esta espécie era conhecida, até o momento, apenas de sua localidade tipo, Ilha Canela, município de Bragança, Pará. A. leptodactyla foi coletada em novembro de 2004, na praia da Baleia, município de Itapipoca $\left(3^{\circ} 08^{\prime} \mathrm{S}, 39^{\circ} 27^{\prime} \mathrm{W}\right)$ e $Z$. ostreum foi obtido a partir do exame de ostras da espécie Crassostrea rhizophorae Guilding, 1828, coletadas em novembro de 2005 no estuário do Rio Jaguaribe, município de Fortim $\left(4^{\circ} 24^{\prime} \mathrm{S}, 37^{\circ} 46^{\prime} \mathrm{W}\right)$. São apresentadas considerações biogeográficas sobre as três espécies assim como uma lista atualizada de todos os pinoterídeos do litoral brasileiro e sua distribuição geográfica.

PALAVRAS-CHAVE. Austinixa; distribuição geográfica; novas ocorrências; Zaops.

Pea crabs of the family Pinnotheridae are a group of small marine and estuarine crabs. Adults can be found free-living or in association with other invertebrates, such as bivalve mollusks, ascidians, worm tubes, callianassid burrows and on or in echinoderms (WILLIAMS 1984).

The pinnotherid group is still poorly known in Brazil. However, over the last years, some studies (listed below) have been published about the taxonomy and systematic aspects, as well as new records of this group for the Brazilian coast.

MARTINS \& D'INCAO (1996) revised the pinnotherid from Santa Catarina and Rio Grande do Sul, Brazil, and found 12 species, where Clypeasterophilus stebbingi Rathbun, 1918, Pinnotheres garthi Fenucci, 1975 and Pinnixa brevipollex Rathbun, 1898, were recorded in Brazil for the first time.
Coelho (1996a) described Alarconia guinotae Coelho, 1996 from Pará to Paraná, Brazil, and recorded Pinnixa floridana Rathbun, 1918 for the first time in Brazilian coast (Coelho 1996b). Still Coelho (1997) revised the genus Pinnixa White, 1846 in Brazil, and described three new species, Pinnixa gracilipes Coelho, 1997, P. Iatissima Coelho, 1997 and P. Ieptodactyla Coelho, 1997. The author observed that the records of P. cristata Rathbun, 1900 in Brazil were, in fact, P. aidae Righi, 1967.

Heard \& Manning (1997) created the genus Austinixa to support eight species previously assigned as Pinnixa, among them, P. aidae. Campos (1999) included the austral species Pinnotheres garthi and P. politus (Smith, 1869) within the genus Calyptraeotheres Campos, 1990.

Melo \& Boehs (2004) rediscovered the so far unrecorded

Revista Brasileira de Zoologia 23 (4): 1038-1043, dezembro 2006 
Pinnaxodes tomentosus Ortmann, 1894, which was only known for the type locality which, according to ORTMANn (1894), is "Bresilien". This species was transferred to the genus Holothuriophilus Nauck, 1880.

Coelho (2005) described Austinixa bragantina from Pará, Brazil, and stated that P. leptodactyla should be referred as A. leptodactyla following the HEARD \& MANNING (1997) proposal.

Finally, HARRISON \& HANLEY (2005), based on discrete morphological and morphometric characters, and mitochondrial DNA sequence data, synonymized A. aidae (Righi, 1967) and A. hardyi Heard \& Manning, 1997. So, A. aidae range was extended to Tobago, West Indies.

The most recent lists of the Brazilian pinnotherid species were provided by Melo (1996, 1998), where are cited 14 species for the coast of Brazil. The present contribution makes three new records of pea crabs from Ceará State, Brazil, with biogeographic considerations regarding the three species and also provides an updated list of all pinnotherid crabs known for the Brazilian coast.

\section{MATERIAL AND METHODS}

Austinixa bragantina was collected with corer on the intertidal zone of Futuro Beach, municipality of Fortaleza, on May and June 1995. A. leptodactyla was obtained by handling on the intertidal zone of Baleia Beach, municipality of Itapipoca, during the activities of the project "Zoneamento Ecológico e Econômico (ZEE) da Zona Costeira do Estado do Ceará", carried out by Instituto de Ciências do Mar (LABOMAR) of Universidade Federal do Ceará, and Superintendência Estadual do Meio Ambiente (SEMACE), on November 2004. Zaops ostreum was observed within the valves of the oyster Crassostrea rhizophorae Guilding, 1828 collected at Jaguaribe River estuary, municipality of Fortim, on November 2005.

The crabs were fixed in $70 \%$ ethanol and deposited in the carcinological collection of LABOMAR. Specimens were identified following Melo (1996) and Coelho (1997, 2005). Material of A. bragantina was compared with the holotype de posited in the carcinological collection of Departamento de Oceanografia da Universidade Federal de Pernambuco (DOCEAN \#13411). Abbreviations: (CL) carapace length and (CW) carapace width.

A list of valid pinnotherid species reported for Brazilian waters, including geographic and bathymetric distribution, is provided in the Appendix.

\section{RESULTS \\ Pinnothereliinae Alcock, 1900 Austinixa bragantina Coelho, 2005}

Fig 1

Material examined. BrazlL, Ceará: Fortal eza (Futuro Beach, 0342'S, 2827'W), 1 male (CL X CW =1.9 X 3.4 mm), 7.V.1995, (LABOMAR\#703), D.O. Monteiro, C.A. Rocha and W. Franklin
Júnior leg.; 1 male (CL X CW = 1.4 X 3.6 mm), 12.VI.1995 (LABOMAR\#704), the same collectors.

Geographic distribution. Western Atlantic, Brazil: Pará (Coelho 2005) and Ceará (present article).

Habitat. Sandy beach. Type material was found in estuarine region, associated with the burrowing callianassid Lepidophtalmus siriboia Felder \& Rodrigues, 1993 and Callichirus major (Say, 1818) (Coelho 2005).

Remarks. The specimens were found unidentified in the carcinological collection of LABOMAR. Details beyond locality and kind of substratum were not available to the authors. However, is known that on the collection site there were callianassid burrows.

\section{Austinixa leptodactyla (Coelho, 1997)} Fig 2

Pinnixa leptodactyla Coelho, 1997: 178, fig 5.

Material examined. BrazIL, Ceará: Itapipoca (Baleia Beach, $\left.3^{\circ} 08^{\prime} \mathrm{S}, 39^{\circ} 27^{\prime} \mathrm{W}\right), 1$ male (CL X CW =2.3 X $6.6 \mathrm{~mm}$ ), 15.XI.2004, (LABOMAR\#705), H. Matthews-Cascon leg.

Geographic distribution. Western Atlantic, Brazil: Pará, Rio Grande do Norte, Pernambuco and Sergipe (Coelho 1997), Ceará (present article).

Habitat. Sandy beach. Previously recorded from muddy bottoms of estuarine regions associated with worm tubes and callianassid burrows. From intertidal zone up to 39 meters. Also collected in association with A. aidae and Pinnixa sayana Stimpson, 1860 (Coelho 1997).

\section{Pinnotherinae De Haan, 1833 Zaops ostreum (Say, 1817)}

Figs 3 and 4

Pinnotheres ostreum Say, 1817: 67, pl. 4, fig. 5.

Pinnotheres depressum Say, 1817: 68.

Zaops depressa Rathbun, 1900: 590.

Pinnotheres depressus Rathbun, 1918: 79, pl. 17, figs 1-2.

Zaops ostreum Manning, 1993: 528, figs 4-5.

Material examined. BRAZIL, Ceará: Fortim (Jaguaribe River estuary, $\left.4^{\circ} 24^{\prime} \mathrm{S}, 37^{\circ} 46^{\prime} \mathrm{W}\right), 1$ male (CL X CW $=3.9 \times 3.1 \mathrm{~mm}$ ) and 2 females $(C L \times C W=6.7 \times 7.5 \mathrm{~mm}$; $6.5 \times 7.6 \mathrm{~mm}$ ), XI.2005, (LABOMAR\#706), R. F. Vasconcelos leg.

Geographic distribution. Western Atlantic, from Massachusetts to southern Florida, Gulf of Mexico, Antilles and Brazil: Ceará (present article); Rio Grande do Norte (SAnKARAnKuttr \& Ferreira 2001); Pernambuco (Coelho \& Ramos 1972); Bahia and Rio de Janeiro (Martins \& D'Incao 1996); São Paulo (Dall'Occo et al. 2004); and Santa Catarina (Klein et al. 2001).

Habitat. Commensal in oysters (Crassostrea rhizophorae) and bivalves of the genera Anomia Linnaeus, 1758, Mytilus Linnaeus, 1758 and Pecten Muller, 1776. Occasionally in polychaete tubes, mainly Chaetopterus variopedatus (Renier, 1804) 


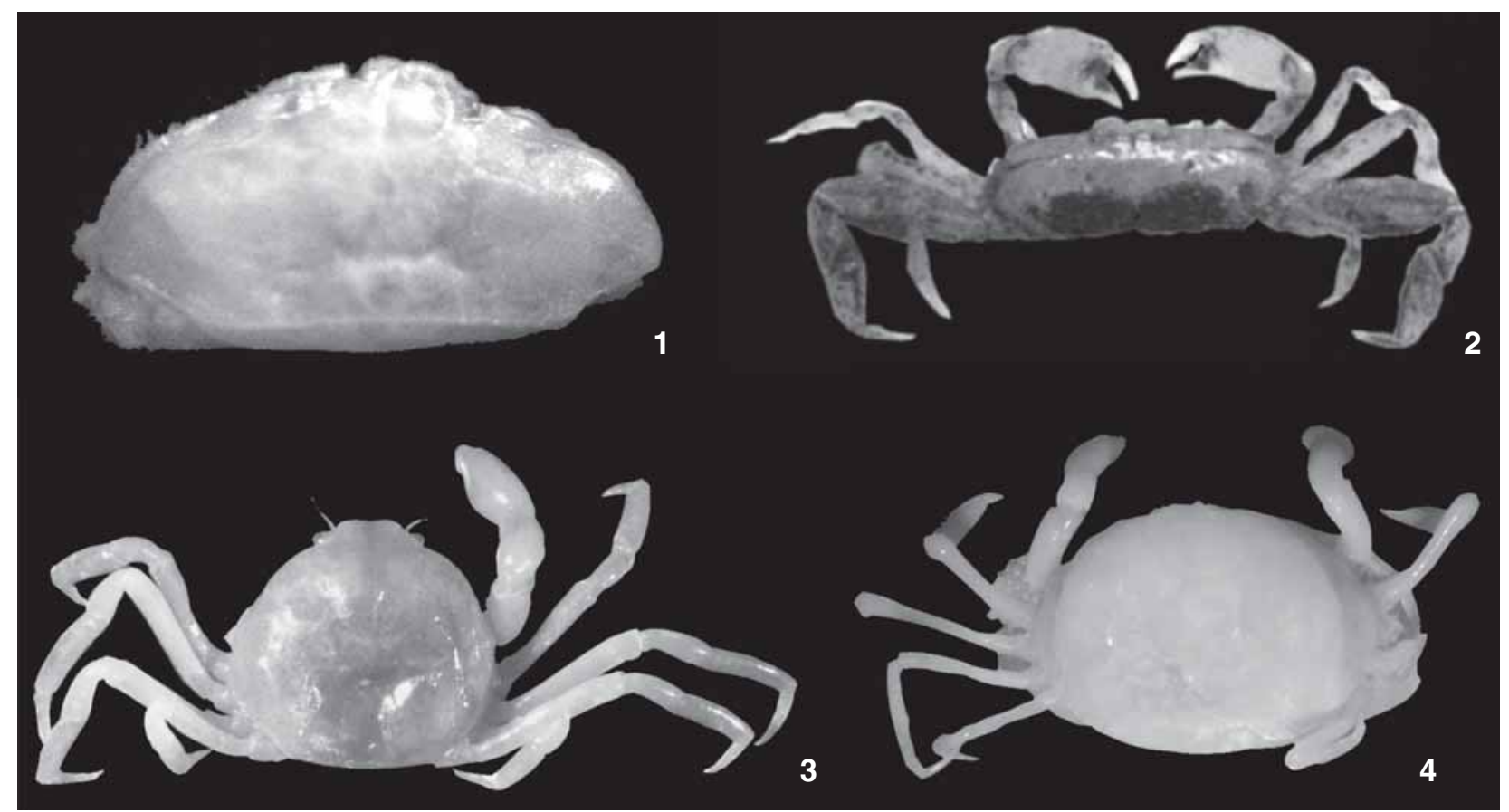

Figure 1-4. Pinnotherid crabs from Ceará, Brazil. (1) Austinixa bragantina male, CW =3.6 mm, LABOMAR\#704; (2) Austinixa leptodactyla male, CW =6.6 mm, LABOMAR\#705; (3) Zaops ostreum, male, CW = $3.1 \mathrm{~mm}$, LABOMAR\#706 (4) Z. ostreum, female, CW =7.6 mm, LABOMAR\#706.

(Melo 1996). On the Gulf of Mexico can be found associated with Crassostrea virginica (Gmelin, 1791), C. rhizophorae, Anomia simplex Orbigny, 1842, Mytilus edulis (Orbigny, 1846) and Pecten sp. (Powers 1977).

Remarks. Williams (1965), Coelho \& Ramos (1972), Powers (1977), Williams (1984), Martins \& D'Incao (1996), Melo $(1996,1998)$ and SPIVAK $(1997)$ pointed out Santa Catarina State as the southern limit to $Z$. ostreum, but these authors did not analyzed material from this State. The only contribution knows to mention specimens collected from Santa Catarina is KLEIN et al. (2001), that have been obtained Z. ostreum from banks of Euvola ziczac (Linnaeus, 1758).

\section{DISCUSSION}

The task of assigning a species to a zoogeographic province is not as readily done, particularly as species and localities that are not well studied continue to provide new information to distribution data bases (RAz-Guzman et al. 2004). This seems to bethe case of the pinnotherid from the northern South America.

The northern South America has been divided by several authors in zoogeographic provinces (e.g. DANA 1853, BALECH 1951, Coelho 1969, Coelho \& Ramos 1972, Briggs 1974, Coelho et al. 1978, Bosch 2000). In the present article, we adopted the classification proposal by Coelho \& Ramos (1972), which divided the region in two provinces: Guianas and Brazilian. The former extends from the Orinoco River delta, Venezuela, to
Maranhão State, Brazil, and is characterized, mainly, by muddy and sandy bottoms and by the influence of major equatorial rivers (e.g. Orinoco, Amazon and Tocantins Rivers). The latter extends from Maranhão to Rio de Janeiro State, Brazil, being characterized, in a major part, by calcareous al gae bottom and the river discharge does not present an important influence for coastal habitats (Coelho 1969, Coelho \& Ramos 1972).

Coelho (2005) described Austinixa bragantina from Pará State, Brazil, and supposed that this species belongs to the Guianas zoogeographic province. However, the present record extends the geographic range to Ceará State (Fig. 5), which is included in theBrazilian zoogeographic province. A. leptodactyla has al so been recorded to both Guianas and Brazilian provinces (Fig. 5).

Coelho \& Ramos (1972) and Coelho et al. $(1978,1980)$ studying the geographic distribution of stomatopod, isopod and decapod crustaceans in Brazil, Uruguay and Argentina, stated that some species are found, mainly, in the Northeast Brazil with some of them extending to the north, as far as Guianas, and to the south, rarely reaching Uruguay or Argentina, being considered species of the Brazilian zoogeographic province.

Our results show that $A$. bragantina and $A$. leptodactyla are found in Guianas and Brazilian zoogeographic provinces, as other pinnotherid species. Alarconia guinotae and Pinnixa gracilipes for example, are represented in Guianas and Brazilian provinces, with the southern limit reaching the Paulista province (Coelho 1996a, 1997).

Revista Brasileira de Zoologia 23 (4): 1038-1043, dezembro 2006 


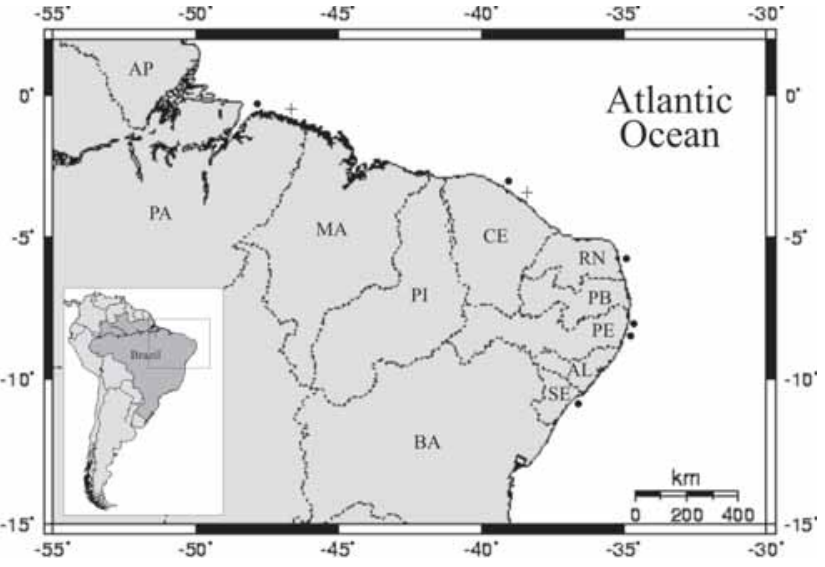

Figure 5. Geographic range of Austinixa bragantina ( + ) and A.

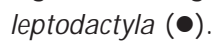

Thus, we suggest that A. bragantina and A. leptodactyla are species from the Brazilian province with the northern limit in the Guianas province. Further collections will certainly amplify the distribution of these species in Western Atlantic.

Geographic distribution of Zaops ostreum seems to be disrupted with a northern group occurring from Massachusetts to Antilles, including the Gulf of Mexico, and the southern group now occurring from Ceará to Santa Catarina (Fig. 6).

Although some decapod species are common to the Caribbean and Brazilian provinces and absent to the Guianas province due the muddy bottoms and low sea water salinity, we believe that $Z$. ostreum has a continuous distribution along Western Atlantic temperate and tropical provinces. Other pinnotherid that present similar range from Massachusetts to southern Brazil or Argentina are Pinnixa chaetopterana Stimpson, 1860, P. sayana and Tumidotheres maculatus (Say, 1818).

The huge gap in the $Z$. ostreum distribution in the northern of South America is probably due the lack of collections in this region. It is important to keep in mind that the geographic range of this species could be influenced by the environmental factors and also by the host distribution.

\section{ACKNOWLEDGEMENTS}

To Sérgio M. de Almeida for the crab pictures; to Cristina de A. Rocha-Barreira, Helena Matthews-Cascon and Régis F. Vasconcelos and Aline F. da Silva for the collection and concession of Austinixa bragantina, A. leptodactyla and Zaops ostreum, respectively. To PROPESQ/UFPE for the PhD scholarship to LEAB, and CNPq (research productivity scholarship PAC). To Paula Christine Jimenez for revising the written English Ianguage.

\section{REFERENCES}

BALECH, E. 1951. División zoogeográfica del litoral sudamericano.

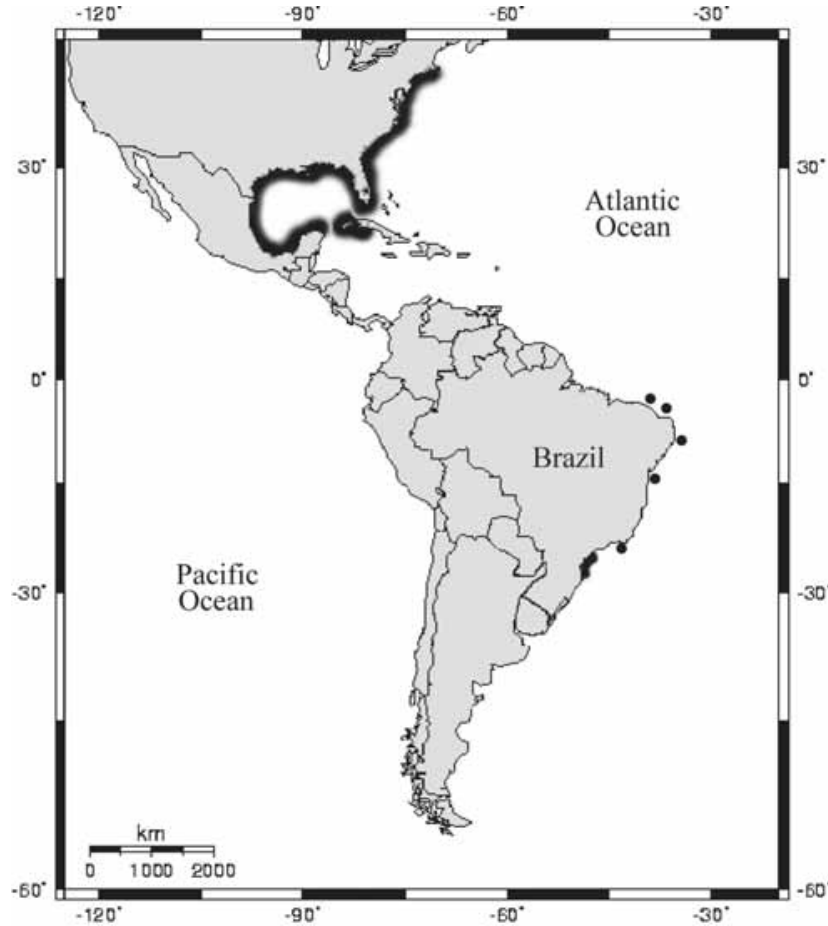

Figure 6. Geographic range of Zaops ostreum.

Revista de Biologia Marina, Val paraíso, 4: 184-195.

BoschI, E.E. 2000. Species of decapod crustaceans and their distribution in the American marine zoogeographic provinces. Revista de Investigación y Desarrollo Pesquero, Mar del Plata, 13: 7-136.

BRIGGS, J.C. 1974. Marine Zoogeography. New York, McGrawHill, XI+455p.

Campos, E. 1999. Inclusion of the austral species Pinnotheres politus (Smith, 1869) and P. garthi Fenucci, 1975 within the genus Calyptraeotheres Campos, 1990 (Crustacea: Brachyura: Pinnotheridae). Proceedings of the Biological Society of Washington, Washington, 112 (5): 536-540.

Coelho, P.A. 1969. A distribuição dos crustáceos decápodos reptantes do Norte do Brasil. Trabalhos Oceanográficos da Universidade Federal de Pernambuco, Recife, 9/11: 223238.

Coelho, P. A. 1996a. Revisão do gênero Alarconia Glassell, 1938, no Brasil, com descrição de Alarconia guinotae sp. nov. (Crustacea, Decapoda). Trabalhos Oceanográficos da Universidade Federal de Pernambuco, Recife, 24: 173-178.

Coelho, P.A. 1996b. Distribuição de Mixtopagurus paradoxus A. MilneEdwards, 1880, Pinnixa floridana Rathbun, 1918 e Osachilla tuberosa Stimpson, 1871 no litoral brasileiro (Crustacea, Decapoda). Trabalhos Oceanográficos da Universidade Federal de Pernambuco, Recife, 24: 165-171.

Coelho, P.A. 1997. Revisão do gênero Pinnixa White, 1846 no Brasil (Crustacea, Decapoda, Pinnotheridae). Trabalhos 
Oceanográficos da Universidade Federal de Pernambuco, Recife, 25: 163-193.

Coelho, P.A. 2005. Descrição de Austinixa bragantina sp. nov. (Crustacea, Decapoda, Pinnotheridae) do litoral do Pará, Brasil. Revista Brasileira de Zoologia, Curitiba, 22 (3): 552555.

Coelho, P.A. \& M.A. Ramos. 1972. A constituição e a distribuição da fauna de decápodos do litoral leste da América do Sul entre as latitudes de 5ㅇN e 39오. Trabalhos Oceanográficos da Universidade Federal de Pernambuco, Recife, 13: 133-236.

Coelho, P.A.; M. Ramos-Porto \& M.L. Koening. 1978. Crustáceos marinhos do Brasil do Uruguai e da Argentina (ao norte do Mar del Plata), considerações biogeográficas. Anais da Universidade Federal Rural de Pernambuco, Recife, 2/3: 227256.

Coelho, P.A.; M. Ramos-Porto \& M.L. Koening. 1980. Biogeografia e bionomia dos crustáceos do litoral equatorial brasileiro. Trabalhos Oceanográficos da Universidade Federal de Pernambuco, Recife, 15: 7-138.

Dall'Occo, P.L.; O. Campos JR \& G.A.S. Melo. 2004. The brachyuran (Crustacea: Decapoda) fauna from the coast of the State of São Paulo. O Mundo da Saúde, São Paulo, 28 (4): 456-462.

DANA, J.B. 1853. An isothermic oceanic chart, illustrating the geographical distribution of marine animal. American Journal of Science, New Haven, 16: 153-167, 314-327.

HaRRISON, J.S. \& P.W. Hanley. 2005. Austinixa aidae Righi, 1967 and A. hardyi Heard and Manning, 1997 (Decapoda: Brachyura: Pinnnotheridae) synonymized, with comments on molecular and morphometric methods in crustacean taxonomy. Journal of Natural History, London, 39 (42): 3649-3662.

Heard, R.W. \& R.B. Manning. 1997. Austinixa, a new genus of pinnotherid crab (Crustacea: Decapoda: Brachyura), with the description of A. hardyi, a new species from Tobago, West Indies. Proceedings of the Biological Society of Washington, Washington, 110 (3): 393-398.

Klein, J.A.; C.A. Borzone \& P.R. Pezzuto. 2001. A macro e megafauna bêntica associada aos bancos da vieira Euvola ziczac (Mollusca: Bivalvia) no litoral sul do Brasil. Atlântica, Rio Grande, 23: 17-26.

M ANNING, R.B. 1993. Three genera removed from the synonymy of Pinnotheres Bosc, 1802 (Brachyura: Pinnotheridae). Proceedings of the Biological Society of Washington, Washington, 106 (3): 523-531.

Martins, S.T.S. \& F. D'Incao. 1996. Os Pinnotheridae de Santa Catarina e Rio Grande do Sul, Brasil (Decapoda, Brachyura). Revista Brasileira de Zoologia, Curitiba, 13 (1): 1-26.

Melo, G.A.S. 1996. Manual de identificação dos Brachyura (caranguejos e siris) do litoral brasileiro. São Paulo, Editora Plêiade, 603p.

Melo, G.A.S. 1998. Malacostraca - Eucarida. Brachyura,
Oxyrhyncha and Brachyrhyncha, p. 455-515. In: P.S. Young (Ed.). Catalogue of Crustacea of Brazil. Rio de Janeiro, Museu Nacional, XVII+717p.

Melo, G.A.S. 1999. Infraordem Brachyura (siris e caranguejos: espécies marinhas e estuarinas), p. 415-485. In: L. Buckup \& G. Bond-Buckup (Eds). Os Crustáceos do Rio Grande do Sul. Porto Alegre, Editora da Universidade Federal do Rio Grande do Sul, 503p.

Melo, G.A.S. \& G. Boens. 2004. Rediscovery of Holothuriophilus tomentosus (Ortmann) comb. nov. (Crustacea, Brachyura, Pinnotheridae) in the Brazilian coast. Revista Brasileira de Zoologia, Curitiba, 21 (2): 229-232.

Ortmann, A.E. 1894. Abtheilung: Brachyura (Brachyura Genuina Boas), III. Unterabtheilung: Cancroidea, 2. Section: Cancrinea, 2. Gruppe: Catometopa, Die Decapoden-Krebse des Strassburger Museums, mit besonderer Berüksichtigung der von Hern Dr. Doderlein bei Japan und bei den Liu-Kiu Inseln gesammelten und Zeit im Strassburger Museum aufbewahrten Former, VIII. Zoologische Jahrbücher, Abteilungen Systematik, Geographie der Tiere, Jena, 7: 683-772.

Powers, L.W. 1977. A catalogue and bibliography to the crabs (Brachyura) of the Gulf of M exico. Contributionsin Marine Science, Port Aransas, 20 (Suppl.): 1-190.

Rathbun, M.J. 1900. The catametopous or grapsoid crabs of North America. American Naturalist, Salem, 34: 183-192.

Rathbun, M.J. 1918. The Grapsoid crabs of America. Bulletin of the United States National Museum, Washington, 97: 1-445.

Raz-Guzman, A.A.; J. Sánchez; P. Peralta \& R. Florido. 2004. Zoogeography of hermit crabs (Decapoda: Diogenidae, Paguridae) from four coastal lagoons in the Gulf of Mexico. Journal of Crustacean Biology, Lawrence, 24 (4): 625636.

RıGHI, G. 1967. Sobre alguns Decapoda do Brasil (Crustacea: Brachyura: Pinnotheridae e Parthenopidae). Papéis Avulsos do Departamento de Zoologia, São Paulo, 20 (10): 99116.

Sankarankutty, C. \& A.C. Ferreira. 2001. Dimorphism in males of Zaops ostreum (Say) (Crustacea, Decapoda, Pinnotheridae). Revista Brasileira de Zoologia, Curitiba, 18 (4): 1343-1344.

SAY, T. 1817. An account of the Crustacea of the United States. Journal of the Academy of Natural Sciences of Philadelphia, Philadel phia, 1 (1): 65-80.

SPIVAK, E.D. 1997. Los crustáceos decápodos del Atlántico sudoccidental (25-55으): distribución y ciclos de vida. Investigaciones Marinas, Val paraíso, 25: 69-91.

Williams, A.B. 1965. Marine Decapod Crustaceans of the Carolines. Fishery Bulletin, Washington, 65 (1): 1-298.

Williams, A.B. 1984. Shrimps, Lobsters and Crabs of the Atlantic coast of the Eastern United States, Maine to Florida. Washington, Smithsonian Institution Press, XVIII+ 550p.

Revista Brasileira de Zoologia 23 (4): 1038-1043, dezembro 2006 
Appendix. List and distribution of valid Brazilian Pinnotheroidea species

Pinnotheroidea De Haan, 1883

Pinnotheridae De Haan, 1883

Pinnothereliinae Alcock, 1900

Alarconia guinotae Coelho, 1996: Western Atlantic, Brazil: Pará, Alagoas, São Paulo and Paraná; intertidal to 25 m.

Austinixa aidae (Righi, 1967): Western Atlantic, Tobago, Brazil: from Amapá to Rio Grande do Sul; intertidal to 32 m. Species referred as Pinnixa aidae Righi, 1967 in Melo (1996, 1998).

Austinixa bragantina Coelho, 2005: Western Atlantic, Brazil: Pará and Ceará; intertidal.

Austinixa leptodactyla (Coelho, 1997): Western Atlantic, Brazil: Pará, Ceará, Rio Grande do Norte, Pernambuco and Sergipe; intertidal to $39 \mathrm{~m}$.

Austinixa patagoniensis (Rathbun, 1918): Western Atlantic, Brazil: from Rio de Janeiro to Rio Grande do Sul and Argentina: Rio Negro; intertidal. Species referred as Pinnixa patagoniensis Rathbun, 1918 in Melo (1996, 1998, 1999).

Holothuriophilus tomentosus (Ortmann, 1894): Western Atlantic, Brazil: Santa Catarina. No information on bathymetric distribution available. Species referred as Pinnaxodes tomentosus Ortmann, 1894, in Melo (1996, 1998).

Pinnixa brevipollex Rathbun, 1898: Western Atlantic, Brazil: from Rio de Janeiro to Rio Grande do Sul and Argentina: Rio Negro; intertidal to $130 \mathrm{~m}$. Previously recorded to Brazil as Pinnixa rapax Bouvier, 1917 (Righi 1967, Coelho \& Ramos, 1972, Melo 1996, 1998, 1999).

Pinnixa chaetopterana Stimpson, 1860: Western Atlantic, from Massachusetts to North Carolina, Florida, Gulf of Mexico and Brazil: from Pernambuco to Rio Grande do Sul; intertidal to $60 \mathrm{~m}$.

Pinnixa floridana Rathbun, 1918: Western Atlantic, North Carolina, Florida and Brazil: Maranhão and Pernambuco; intertidal to $21 \mathrm{~m}$.

Pinnixa gracilipes Coelho, 1997: Western Atlantic, Brazil: Pará, Pernambuco and São Paulo; intertidal to 25 m.

Pinnixa latissima Coelho, 1997: Western Atlantic, Brazil: Pernambuco and Bahia; no information on bathymetric distribution available.

Pinnixa sayana Stimpson, 1860: Western Atlantic, from Massachusetts to Brazil: from Amapá to Rio Grande do Sul; intertidal to $80 \mathrm{~m}$.

Pinnotherinae De Haan, 1833

Calyptraeotheres garthi (Fenucci, 1975): Western Atlantic, Brazil: Rio Grande do Sul and Argentina: Gulf of San Matias; 24 m.

Clypeasterophilus stebbingi (Rathbun, 1918): Western Atlantic, Florida and Brazil: São Paulo and Santa Catarina; no information on bathymetric distribution available.

Dissodactylus crinitichelis Moreira, 1901: Western Atlantic, from North Carolina to Brazil: from Pará to Rio Grande do Sul and Argentina: Río de la Plata; intertidal to $52 \mathrm{~m}$.

Fabia insularis Melo, 1971: Western Atlantic, Brazil: from Rio de Janeiro to Rio Grande do Sul and Argentina: Mar del Plata; shallow waters to $30 \mathrm{~m}$. Species revalidated by MARTINS \& D'INCAO (1996).

Fabia sebastianensis Rodrigues da Costa, 1970: Western Atlantic, Brazil: from Rio de Janeiro to Rio Grande do Sul and Argentina: Mar del Plata; no information on bathymetric distribution available.

Parapinnixa bouvieri Rathbun, 1918: Western Atlantic, from North Carolina to Brazil: Amapá; 5 to 75 m.

Parapinnixa hendersoni Rathbun, 1918: Western Atlantic, from Florida to Brazil: from Maranhão to Paraná; 40 to 60 m.

Pinnotheres emiliai Melo, 1971: Western Atlantic, Brazil: from Rio de Janeiro to Rio Grande do Sul and Argentina: Mar del Plata; 5 to 25 m. Species referred as Fabia emiliai (Melo, 1971) in Melo $(1996,1998)$ and revalidated by MARTINS \& D' INCAO (1996).

Tumidotheres maculatus (Say, 1818): Western Atlantic, from Massachusetts to Brazil: from Alagoas to Santa Catarina and Uruguay to Argentina; intertidal to $50 \mathrm{~m}$.

Zaops ostreum (Say, 1817): Western Atlantic, from Massachusetts to southern Florida, Gulf of Mexico, Antilles and Brazil: from Ceará to Santa Catarina; intertidal.

Received in 29.III.2006; accepted in 03.X.2006. 